\title{
Association of multidimensional poverty and tuberculosis in India
}

\author{
Dimpal Pathak', Guru Vasishtha ${ }^{2^{*}}$ (D) and Sanjay K. Mohanty ${ }^{3}$
}

\begin{abstract}
Background: Reduction of multidimensional poverty and tuberculosis are priority development agenda worldwide. The SDGs aims to eradicate poverty in all forms (SDG 1.2) and to end tuberculosis (SDG 3.3.2) by 2030. While poverty is increasingly being measured across multiple domains, reduction of tuberculosis has been an integral part of public health programmes. Though literature suggests a higher prevalence of tuberculosis among the economically poor, no attempt has been made to understand the association between multidimensional poverty and tuberculosis in India. The objective of this paper is to examine the association of multidimensional poverty and tuberculosis in India.

Methods: The unit data from the National Family Health Survey-4, conducted in 2015-16 covering 628,900 households and 2,869,043 individuals across 36 states and union territories of India was used in the analysis. The survey collected information on the self-reported tuberculosis infection of each member of a sample household at the time of the survey. Multidimensional poverty was measured in the domains of education, health, and standard of living, with a set of 10 indicators. The prevalence of tuberculosis was estimated among the multidimensional poor and non-poor populations across the states of India. A binary logistic regression model was used to understand the association of tuberculosis and multidimensional poverty.

Results: Results suggest that about 29.3\% population of India was multidimensional poor and that the multidimensional poverty index was 0.128 . The prevalence of tuberculosis among the multidimensional poor was 480 (95\% Cl: 464-496) per 100,000 population compared to 250 (95\% Cl: 238-262) among the multidimensional non-poor. The prevalence of tuberculosis among the multidimensional poor was the highest in the state of Kerala (1590) and the lowest in the state of Himachal Pradesh (220). Our findings suggest a significantly higher prevalence of tuberculosis among the multidimensional poor compared to the multidimensional non-poor in most of the states in India. The odds of having tuberculosis among the multidimensional poor were 1.82 times higher $(95 \% \mathrm{Cl}$, 1.73-1.90) compared to the non-poor. Age, sex, smoking, crowded living conditions, caste, religion, and place of residence are significant socio-demographic risk factors of tuberculosis.
\end{abstract}

Conclusion: The prevalence of tuberculosis is significantly higher among the multidimensional poor compared to the multidimensional non-poor in India.

Keywords: Multidimensional poverty, Non-poor, Poverty, Tuberculosis, India

\footnotetext{
* Correspondence: guruvasishth15@gmail.com

${ }^{2}$ International Institute for Population Sciences, Govandi Station Road, Deonar, Mumbai, Maharashtra 400088, India

Full list of author information is available at the end of the article
}

(c) The Author(s). 2021 Open Access This article is licensed under a Creative Commons Attribution 4.0 International License, which permits use, sharing, adaptation, distribution and reproduction in any medium or format, as long as you give appropriate credit to the original author(s) and the source, provide a link to the Creative Commons licence, and indicate if changes were made. The images or other third party material in this article are included in the article's Creative Commons licence, unless indicated otherwise in a credit line to the material. If material is not included in the article's Creative Commons licence and your intended use is not permitted by statutory regulation or exceeds the permitted use, you will need to obtain permission directly from the copyright holder. To view a copy of this licence, visit http://creativecommons.org/licenses/by/4.0/. The Creative Commons Public Domain Dedication waiver (http://creativecommons.org/publicdomain/zero/1.0/) applies to the data made available in this article, unless otherwise stated in a credit line to the data. 


\section{Introduction}

Globally, about 10 million people were suffering from tuberculosis with estimated 1.4 million deaths in 2019 [1]. Tuberculosis is the 9th leading cause of death worldwide [1]. Among 11 countries in the WHO South-East Asia region, five, namely Bangladesh, India, Indonesia, Myanmar, and Thailand, account for $95 \%$ of the infected tuberculosis cases [2]. HIV, diabetes, viral hepatitis, and empyema are some of the disease-related risk factors of tuberculosis [3-5]. The WHO has placed a multisectoral strategy to end tuberculosis by 2030 .

Tuberculosis is a contagious disease, requiring longterm treatment and care, that has social stigma associated with it. The prevalence of tuberculosis varies with the living conditions and the social and economic characteristics of the households. Tuberculosis has been more prevalent among the economically poor since time immemorial [6]. Studies suggest a strong and positive association of tuberculosis with poverty, illiteracy, unemployment, and catastrophic health spending [2, 7-10]. Lack of access to health care, deficient nutrition, and inadequate living conditions are some of the causes of the spread of tuberculosis. Besides, scarcity and inadequate quality of food, overcrowded habitation, and homelessness escalate tuberculosis transmission [8].

Traditionally, poverty has been estimated only in the economic domain (referred to as money-metric poverty). In recent literature, the practice has been to measure poverty across multiple domains, including health, education, economy, and environment. A growing number of studies have estimated multidimensional poverty both globally and nationally $[11,12]$. In the recent years, the Oxford Poverty and Human Development Initiative (OPHI) has been providing global estimates of multidimensional poverty for more than 100 countries [12]. The Sustainable Development Goal (SDG) 1 aims to eradicate extreme poverty in all its forms everywhere while SDG-3 aims to end the TB epidemic by 2030 [13]. Eradication of multidimensional poverty is a key priority development agenda globally, nationally, and locally.

In accordance with SDG 1 and 3, reduction of both tuberculosis and multidimensional poverty accorded high priority in India. While the positive association of money-metric poverty with tuberculosis is well established $[7,10,14]$, deprivations in multiple domains, such as education, nutrition, morbidity, sanitation, and hygiene, may increase the vulnerabilities to the tuberculosis infections. In 2019, India, with an estimate of 2.6 million tuberculosis infections accounted for one-fourth of the global infections [1]. Between 2005 and 06 and 2015-16, the overall prevalence of tuberculosis in the country decreased from 418 persons to 305 per 100,000 population [15]. India is also home to 364 million multidimensional poor population [16], though multidimensional poverty had declined from $54.7 \%$ in $2005-06$ to $27.5 \%$ by $2015-$ 16 [17]. While the prevalence of both tuberculosis and multidimensional poverty has been declining in the country, the inter-state variations in both these variables are large. To our knowledge, no attempt has been made so far to understand the association of multidimensional poverty with tuberculosis in India. Besides, prior studies in India have mostly been carried out on small unrepresentative samples and are limited geographical coverage. The aim of this paper is to provide the estimates of tuberculosis among multidimensional poor and non-poor and understand the association of tuberculosis and multidimensional poverty in India.

\section{Methods \\ Data}

Data from the fourth round of the National Family Health Survey (NFHS-4), 2015-16, India was used in the analysis. The NFHS-4 is a nation-wide, cross-sectional, and large-scale demographic health survey conducted under the stewardship of the Ministry of Health and Family Welfare (MoHFW), Government of India. It used multi-stage stratified systematic sampling to draw representative estimates at the national and subnational levels (state/district level). In the first stage, villages in the case of rural areas and census enumeration blocks in the case of urban areas were selected through the probabilityproportional-to-size method. Households were selected through a systematic sampling scheme in the second stage of the sampling. The survey successfully collected information from 601,509 households (with a 98\% response rate), covering 2,869,043 individuals throughout the country. The survey used three sets of schedules, namely, the household schedule, the woman schedule, and the man schedule. The household schedule provided information on household amenities (type of house, cooking fuel, drinking water, sanitation, electricity, assets ownership, etc) and basic demographic details for each member of the household (age, educational attainment, caste, religion and relationship to head of the household). The woman schedule was canvassed to women in the 15-49 age group in the domains of fertility, maternal health, child health, nutritional status, mortality, contraception, etc. Similarly, the man schedule collected information on health, marriage, contraception, etc. from men aged 15-54 years. The detailed methodology, sampling design, and survey instruments have been given in the report [15].

The NFHS-4 provides six types of separate data files, namely household, birth, kids, women, men, and person's data file. The person's data file contains all information at the individual level, which includes demographic, educational attainment and some healthrelated information for all members in a household. It 
may be mentioned that the household characteristics, such as electricity, type of house, cooking fuel and household assets, are the same for every member of a household, while the individual characteristics, such as age, sex, educational attainment, and some biomarkers, vary for each member of the household. The individual data file was used to estimate the extent of multidimensional poverty and tuberculosis.

Three specific questions related to tuberculosis were asked to the respondents in the household schedule. First, a screening question on ascertainment of tuberculosis was canvassed (Question No-23). It read as "Does any usual resident of your household suffer from tuberculosis?". If anybody in the household reported tuberculosis, two subsequent questions (Q-24 and Q-24A) were asked that read as "Who suffers from TB in the household?" and "Has the person received medical treatment for it?". Further, information was collected on the place of treatment (private/public facility). Tuberculosis was either self-reported or reported by any some other member of the household. Of the 8718 sample households that have at least one member with tuberculosis, 96.2\% had only one member infected with tuberculosis. The unit data of NFHS-4 is publicly available and can be accessed by registering at www.dhsprogram.com/data/.

\section{Methodology}

Descriptive statistics, multidimensional poverty indices, and logistic regression model were used in the analysis. Descriptive analyses were carried out to estimate the prevalence of tuberculosis across socio-economic and geographic characteristics. We used the Alkire and Foster (AF) method to estimate multidimensional poverty indices in the states of India. The AF method uses a dual cut-off methodology. First, the poor were identified in each weighted indicator based on pre-determined threshold/cut-off points of deprivation for each indicator (column three of Table 1). For instance, all household members were considered to be deprived in a particular indicator, say electricity if the household did not have electricity. In the second step, the aggregation of deprivation was made. Multidimensional poverty was defined at a threshold of $33 \%$ across composite deprivation score in line with global multidimensional poverty literature [18]. We used the estimates of both tuberculosis and multidimensional poverty at the individual level. This is logical as the data on tuberculosis was collected for all members of a household, while multidimensional poverty (similar to the poverty headcount ratio) was estimated at the population level (percentage of population below a threshold level). However, many of the indicators used for estimating multidimensional poverty were at the household level and remained the same for each member in the household. We also included two additional indicators, that is, number of households with at least one-member suffering from tuberculosis and percentage of households who are multidimensional poor.

We used three broad dimensions - education, health, and standard of living - and a total of ten indicators in these three domains to define multidimensional poverty. Each indicator was directly or indirectly related to the SDGs. The inclusion criteria of the indicators and the

Table 1 Dimensions and indicators, deprivation cut-off points, mean and weights used in estimating multidimensional poverty, India, 2015-16

\begin{tabular}{|c|c|c|c|c|c|}
\hline Dimension & Indicator & Deprived if & Weight & Mean & SD \\
\hline \multirow[t]{2}{*}{ Education } & $\begin{array}{l}\text { 1. Years of } \\
\text { Schooling }\end{array}$ & No household member (aged 14+) has completed at least eight years of schooling. & $1 / 6$ & 12.31 & 0.329 \\
\hline & $\begin{array}{l}\text { 2. Current School } \\
\text { attendance }\end{array}$ & Any school-age child in the household (up to grade 8) is not attending school. & $1 / 6$ & 6.87 & 0.253 \\
\hline \multirow[t]{2}{*}{ Health } & 3. Under nutrition & $\begin{array}{l}\text { Any household member is malnourished, as measured by the body mass index for adults } \\
\text { (BMI < 18.5) and by the height-for-age } z \text {-score calculated based on World Health } \\
\text { Organization standards for children under age } 5\end{array}$ & $1 / 6$ & 42.17 & 0.494 \\
\hline & 4. Child mortality & Any child has died in the household within the five years prior to the survey. & $1 / 6$ & 3.75 & 0.19 \\
\hline \multirow{6}{*}{$\begin{array}{l}\text { Standard } \\
\text { of living }\end{array}$} & 5. Electricity & Household is not having access to electricity. & $1 / 18$ & 11.83 & 0.323 \\
\hline & 6. Drinking water & $\begin{array}{l}\text { Household is not having access to clean drinking water or having access to clean drinking } \\
\text { water through a source that is located } 30 \text { min away or more by walking. }\end{array}$ & $1 / 18$ & 14.73 & 0.354 \\
\hline & 7. Sanitation & $\begin{array}{l}\text { Household is not having access to improved sanitation facilities or having access only to } \\
\text { shared improved sanitation facilities. }\end{array}$ & $1 / 18$ & 52.02 & 0.5 \\
\hline & 8. Cooking fuel & Household is using "dirty" cooking fuel (dung, wood or charcoal). & $1 / 18$ & 58.77 & 0.492 \\
\hline & 9.Housing & $\begin{array}{l}\text { The household has inadequate housing: the floor is made of natural materials or the roof or } \\
\text { walls are made of rudimentary materials. }\end{array}$ & $1 / 18$ & 45.51 & 0.498 \\
\hline & 10. Assets & $\begin{array}{l}\text { The household does not own more than one of these assets: radio, TV, telephone, } \\
\text { computer, animal cart, bicycle, motorbike, or refrigerator, and does not own a car or truck. }\end{array}$ & $1 / 18$ & 12.5 & 0.331 \\
\hline
\end{tabular}


deprivation cut off-points for measuring multidimensional poverty have been described elsewhere [18]. The deprivation cut-off point for the school attainment indicator was revised to completion of 8 years of schooling to suit the Indian context. The details of the dimensions, indicators, cut-off points, and weights are given in Table 1. Equal weights were assigned to each dimension, and within a dimension, equal weights were assigned to each indicator. The AF method provides three types of indices, that is, head count ratio, intensity of poverty, and multidimensional poverty index. The present study focuses on using multidimensional poverty since its prime objective was to estimates the prevalence of tuberculosis among multidimensional poor and non-poor. A brief description of the indices is given below.

Head count ratio $(\mathrm{H})$ : It is defined as the proportion of the multidimensionally poor to the total population and can be calculated as:

$$
H=\frac{q}{n}
$$

Where $q$ is the number of persons who are multidimensional poor and $n$ is the total population. We have presented $\mathrm{H}$ as a percentage.

Intensity of poverty (A) is calculated as,

$$
A=\frac{\sum_{1}^{q} c}{q}
$$

Where $\mathrm{c}$ is the deprivation score that the poor experienced. It is an average weighted count of deprivation experienced by the multidimensional poor.

Multidimensional poverty index (MPI) is the product of headcount ratio and intensity of poverty and calculated as:

$$
M P I=H * A
$$

A chi-square test was carried out to understand the significant association between the prevalence of tuberculosis and the various characteristics considered in the study. A two sample proportions test was used to find out whether the difference between the prevalence of tuberculosis among the multidimensional poor and the non-poor was significant. We have also estimated Moran's I statistic for tuberculosis and multidimensional poverty to see the extent of spatial clustering.

We used a binary logistic regression analysis to understand the risk factors associated with tuberculosis. Tuberculosis (the outcome variable) was categorized as 0 (absence of the disease) and 1 (presence of the disease). The most common mathematical equation used for the logistic regression modelling is as follows:

$$
\begin{aligned}
\operatorname{logit}(p)=\ln \left(\frac{p}{1-p}\right)= & \beta_{0}+\beta_{1} X_{1}+\beta_{2} X_{2}+\cdots \\
& +\beta_{i} X_{i}
\end{aligned}
$$

Where $\mathrm{p}$ is the probability of having tuberculosis and $\beta_{i}$ are the regression coefficients indicating the relative effect of changing a particular risk factor (the explanatory variable) on tuberculosis. The $X_{i}$ are the independent (explanatory) variables considered in the study such as multidimensional poverty head count ratio, place of residence (rural or urban), religion, caste, smoking behaviour, overcrowding (defined as more than three persons living in one room), sex, and age. We did not included any such variable in the multivariate analysis that was used to estimate multidimensional poverty. We interpreted the results in terms of odds ratio (OR), with a 95\% confidence interval and provided the robust standard error of the estimates. The confidence interval (CI) are based on robust standard error. All statistical analyses were performed in the STATA version 14 software package. All methods were carried out in accordance with relevant guidelines and regulations.

\section{Results}

Table 1 presents the descriptive statistics of the variables used to estimate multidimensional poverty. Among 10 indicators, the largest deprivation in India was in cooking fuel, followed by sanitation, housing and nutrition. Deprivation was the lowest in child mortality, followed by school attendance.

Figure $1 \mathrm{a}$ and $\mathrm{b}$ presents the state variations in percentage of the multidimensional poor and tuberculosis in India. The red shade in both of the maps shows the high prevalence of multidimensional poverty as well as tuberculosis in the states of India. There were four states, namely, Bihar, Uttar Pradesh, Jharkhand, and Madhya Pradesh, with over $40 \%$ point of multidimensional poor. A total of 12 states had multidimensional poverty between 20 and 40\%, 8 states between 10 and $20 \%$, and 12 states less than $10 \%$. With regard to tuberculosis, we can see a strong regional pattern of clustering at a high level $(>500)$ in the north-eastern states of the country. A second category of states, mainly the states of southern India, had a higher prevalence of tuberculosis and the prevalence was relatively lower in the northern state of Punjab (150). In Bihar, the prevalence of both multidimensional poverty and tuberculosis was high.

Table 2 shows the point estimates of percentage of multidimensional poor, intensity of poverty, the multidimensional poverty index, and the prevalence of tuberculosis (per 100,000 population) in the states of India. The 


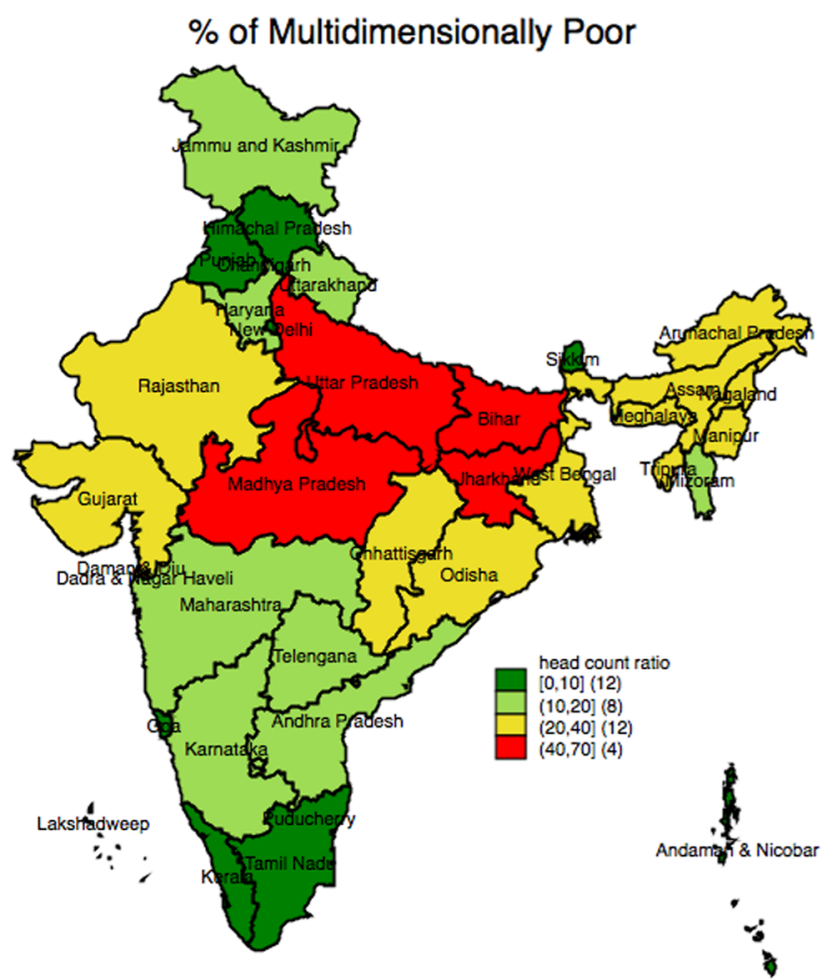

b

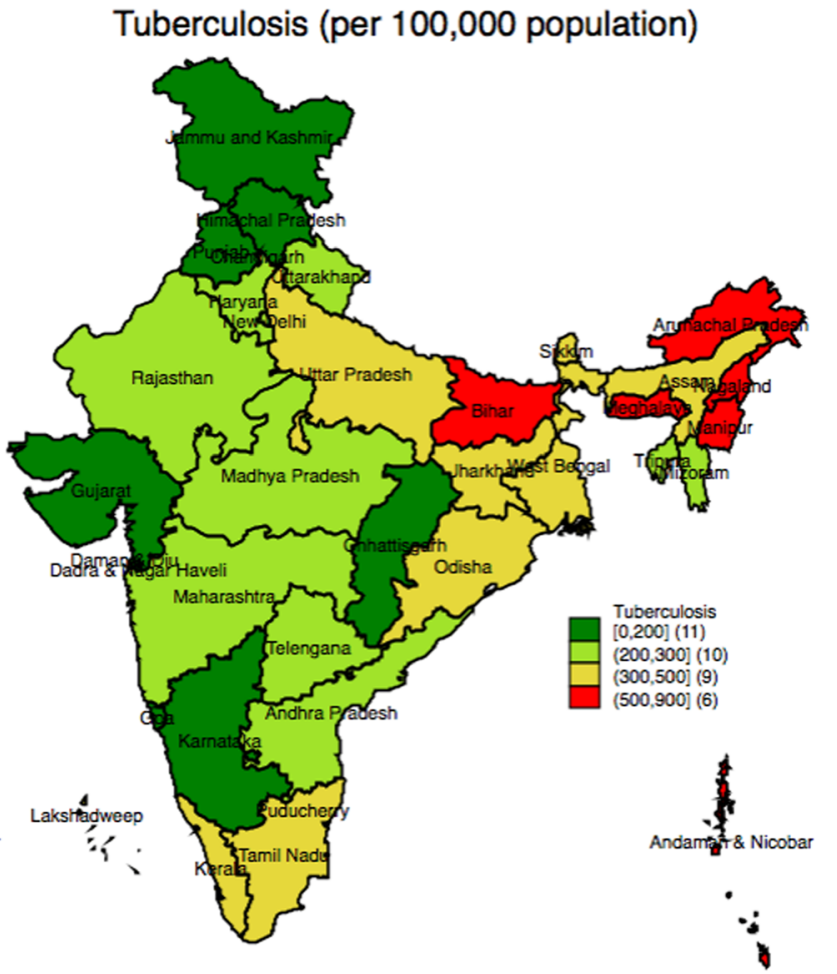

Fig. 1 a Percentage of multidimensionally poor in the states of India, 2015-16; b Prevalence of tuberculosis (per 100,000 population) in the states of India, 2015-16

estimates are provided for the entire sample population (individuals) and at the household level. In India, 29.3\% population was multidimensional poor, and the MPI was estimated at 0.13 . The extent of multidimensional poverty varied from $55.6 \%$ in Bihar to $1.0 \%$ in Kerala. The prevalence of tuberculosis in India was estimated at 310 per 100,000 population. The highest prevalence of tuberculosis was found in the state of Arunachal Pradesh (840 per 100,000 population), followed by Manipur (710 per 100,000 population) and Nagaland (650 per 100,000 population). The state variations in the prevalence of multidimensional poverty and tuberculosis were large. Figure 2 a shows the prevalence of tuberculosis among the multidimensional poor and multidimensional non-poor in India. The prevalence of tuberculosis among the multidimensional poor in India was 480 (per 100,000 population) [95\% CI: 464-496] compared to 250 per (100,000 population) [95\% CI: $238-$ 262] among the non-poor. The prevalence of tuberculosis among the multidimensional poor households, with at least one member suffering from tuberculosis, was 2190 compared to 1100 among the multidimensional non-poor households (Fig. 2b). Such variations highlight the higher prevalence of tuberculosis among the multidimensional poor households in India. Moran's I statistic of multidimensional poverty was 0.46 and that of tuberculosis was 0.38 .
Table 3 presents the prevalence of tuberculosis per 100,000 population among the multidimensional poor and non-poor at the individual and household in the states of India. The variation in the prevalence of tuberculosis was higher among the multidimensional poor than among the non-poor individuals and households in most of the states of India. Among the multidimensional poor, the state of Kerala had the highest prevalence of tuberculosis (1590 per 100,000 population), followed by Delhi (1280 per 100,000 population) and Bihar (810 per 100,000 population). The prevalence of tuberculosis was lowest in Himachal Pradesh (220 per 100,000 population), followed by Jammu \& Kashmir (230 per 100,000 population) and Chhattisgarh (260 per 100,000 population). Among the multidimensional non-poor, the prevalence of tuberculosis was the highest in Bihar (490 per 100,000 population), followed by Kerala (360 per 100,000 population) and Tamil Nadu (330 per 100,000 population). At household level, the prevalence of tuberculosis among multidimensional poor was highest in Delhi (6000 per 100,000 household) followed by Kerala (5162 per 100,000 households) and Bihar (2436 per 100,000 households). Similarly, the prevalence of tuberculosis among multidimensional nonpoor household was highest in Bihar (2436 per 100,000 households) followed 
Table 2 Percentage of multidimensionally poor and intensity of poverty, multidimensional poverty index, and prevalence of tuberculosis (per 100,000 population) in the states of India, 2015-16

\begin{tabular}{|c|c|c|c|c|c|c|c|}
\hline $\begin{array}{l}\text { Sr. } \\
\text { No }\end{array}$ & States & $\begin{array}{l}\text { Percentage } \\
\text { multidimensional } \\
\text { Poor population } \\
\text { (H) }\end{array}$ & $\begin{array}{l}\text { Intensity } \\
\text { of } \\
\text { poverty } \\
(\mathrm{A} \%)\end{array}$ & $\begin{array}{l}\text { Multidimensional } \\
\text { poverty Index }\end{array}$ & $\begin{array}{l}\text { Prevalence of } \\
\text { tuberculosis per } \\
100,000 \text { population } \\
(95 \% \mathrm{Cl})\end{array}$ & $\begin{array}{l}\text { Prevalence of tuberculosis per } \\
100,000 \text { households (at least one } \\
\text { member suffering from TB) (95\% } \\
\mathrm{Cl} \text { ) }\end{array}$ & $\begin{array}{l}\text { Percentage } \\
\text { multidimensional } \\
\text { Poor households } \\
\text { (H \%) }\end{array}$ \\
\hline 1 & Kerala & 1.03 & 37.74 & 0.003 & $370(366-374)$ & $1400(1337-1464)$ & 1.2 \\
\hline 2 & Lakshadweep & 2.04 & 36.15 & 0.007 & $390(375-405)$ & $2093(1800-2386)$ & 0.9 \\
\hline 3 & Puducherry & 3.68 & 36.26 & 0.013 & 140(134-146) & $539(461-617)$ & 4.4 \\
\hline 4 & Delhi & 4.12 & 40.88 & 0.017 & $210(205-215)$ & $951(877-1025)$ & 3.6 \\
\hline 5 & Sikkim & 5.53 & 37.87 & 0.021 & $470(463-477)$ & $1831(1720-1942)$ & 4.9 \\
\hline 6 & Chandigarh & 5.37 & 42.68 & 0.023 & $90(80-100)$ & $371(236-507)$ & 4.3 \\
\hline 7 & Goa & 6.49 & 36.53 & 0.024 & 70(64-76) & $293(210-376)$ & 5.5 \\
\hline 8 & Tamil Nadu & 6.66 & 37.37 & 0.025 & $350(347-353)$ & $1316(1275-1357)$ & 8.7 \\
\hline 9 & Punjab & 6.19 & 40.87 & 0.025 & $150(147-153)$ & $725(686-765)$ & 6.0 \\
\hline 10 & $\begin{array}{l}\text { Andaman } \\
\text { and Nicobar }\end{array}$ & 7.17 & 38.69 & 0.028 & $610(600-620)$ & $2425(2254-2596)$ & 7.9 \\
\hline 11 & $\begin{array}{l}\text { Daman and } \\
\text { Diu }\end{array}$ & 7.18 & 40.72 & 0.029 & $50(44-56)$ & $189(120-257)$ & 5.2 \\
\hline 12 & $\begin{array}{l}\text { Himachal } \\
\text { Pradesh }\end{array}$ & 8.76 & 37.25 & 0.033 & $140(137-143)$ & $609(560-658)$ & 8.6 \\
\hline 13 & Haryana & 11.25 & 42.25 & 0.048 & $230(227-233)$ & 1138(1091-1186) & 10 \\
\hline 14 & Mizoram & 11.28 & 44.76 & 0.051 & $250(246-254)$ & 1127(1069-1185) & 9.9 \\
\hline 15 & $\begin{array}{l}\text { Andhra } \\
\text { Pradesh }\end{array}$ & 14.37 & 40.84 & 0.059 & $300(296-304)$ & $1187(1124-1250)$ & 16.6 \\
\hline 16 & Telangana & 16.33 & 40.49 & 0.066 & $300(295-305)$ & 1170(1099-1241) & 18.3 \\
\hline 17 & Karnataka & 17.88 & 39.75 & 0.071 & 180(178-182) & 757(724-791) & 16.9 \\
\hline 18 & $\begin{array}{l}\text { Jammu and } \\
\text { Kashmir }\end{array}$ & 17.35 & 41.37 & 0.072 & $160(158-162)$ & $824(784-864)$ & 14.5 \\
\hline 19 & Maharashtra & 17.58 & 41.08 & 0.072 & $240(238-242)$ & 1071(1034-1108) & 16.2 \\
\hline 20 & Uttarakhand & 18.29 & 41.42 & 0.076 & $250(247-253)$ & 1119(1069-1169) & 16.6 \\
\hline 21 & Tripura & 20.59 & 42.6 & 0.088 & $250(244-256)$ & 1011(923-1099) & 21 \\
\hline 22 & Gujarat & 22.15 & 42.3 & 0.094 & 180(178-182) & $807(770-845)$ & 19.8 \\
\hline 23 & Manipur & 23.68 & 40.23 & 0.095 & $710(706-714)$ & $3115(303-3199)$ & 20.8 \\
\hline 24 & Nagaland & 26.55 & 41.25 & 0.11 & $650(646-654)$ & $2537(2456-2617)$ & 23.1 \\
\hline 25 & $\begin{array}{l}\text { Arunachal } \\
\text { Pradesh }\end{array}$ & 25.41 & 43.65 & 0.111 & $840(837-843)$ & $3226(3150-3302)$ & 23.6 \\
\hline 26 & West Bengal & 27.01 & 41.59 & 0.112 & $350(346-354)$ & $1417(1361-1472)$ & 27 \\
\hline 27 & Rajasthan & 32.94 & 44.97 & 0.148 & $210(208-212)$ & 1067(1034-1099) & 32 \\
\hline 28 & $\begin{array}{l}\text { Dadra and } \\
\text { Nagar Haveli }\end{array}$ & 35.85 & 42.05 & 0.151 & $150(138-162)$ & $714(530-898)$ & 27.4 \\
\hline 29 & Meghalaya & 34.94 & 44.38 & 0.155 & $550(545-555)$ & $2675(2574-2776)$ & 30.9 \\
\hline 30 & Chhattisgarh & 37.85 & 41.15 & 0.156 & $160(158-162)$ & $763(727-800)$ & 38.5 \\
\hline 31 & Odisha & 37.01 & 43.07 & 0.159 & $330(327-333)$ & $1377(1338-1416)$ & 36.4 \\
\hline 32 & Assam & 38.22 & 44.22 & 0.169 & $310(307-313)$ & 1382(1338-1425) & 35.4 \\
\hline 33 & $\begin{array}{l}\text { Madhya } \\
\text { Pradesh }\end{array}$ & 42.67 & 43.99 & 0.188 & $220(218-222)$ & 1058(1031-1084) & 40.9 \\
\hline 34 & $\begin{array}{l}\text { Uttar } \\
\text { Pradesh }\end{array}$ & 44.42 & 44.48 & 0.198 & $330(329-331)$ & 1748(1721-1775) & 40.9 \\
\hline 35 & Jharkhand & 49 & 44.32 & 0.217 & $320(317-323)$ & 1544(1500-1588) & 45.8 \\
\hline \multirow[t]{2}{*}{36} & Bihar & 55.58 & 46.85 & 0.26 & $640(638-642)$ & $3282(3234-3330)$ & 52.7 \\
\hline & India & 29.28 & 43.68 & 0.128 & $310(309-311)$ & $1390(1381-1398)$ & 27.8 \\
\hline
\end{tabular}


a

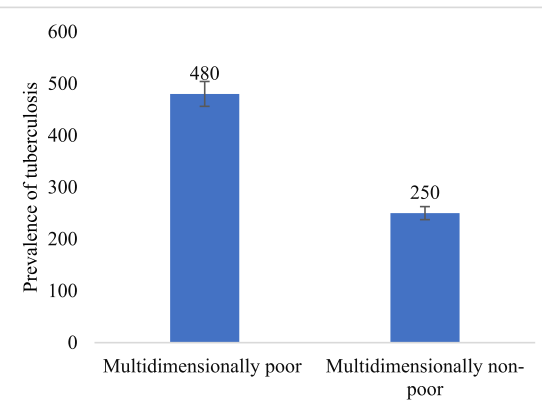

b

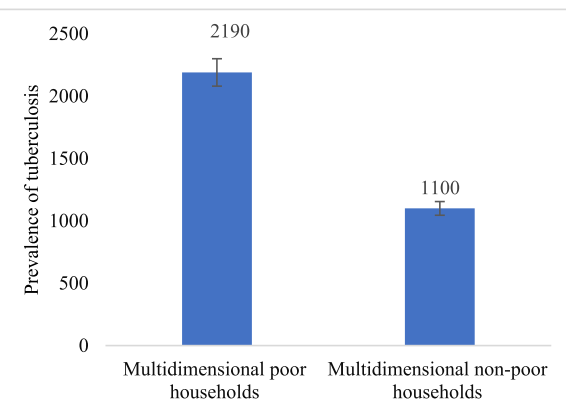

Fig. 2 a Prevalence of tuberculosis by multidimensional poor and non-poor persons; $\mathbf{b}$ Prevalence of tuberculosis (at least one member in the household suffering from tuberculosis) by multidimensional poor and non-poor households in India, 2015-16

by Uttar Pradesh (1382 per 100,000 households). The difference in the prevalence of tuberculosis among the multidimensional poor and non-poor was high and significant in most of the states of India. The pattern of the prevalence of tuberculosis by multidimensional poverty at individual and household levels was similar across the states of India.

Table 4 shows the prevalence of tuberculosis by selected sociodemographic factors among the multidimensional poor and non-poor (individuals) in India. The prevalence of the disease was higher among the multidimensional poor than non-poor across socio-demographic characteristics. Urban areas had a higher prevalence of tuberculosis (520 per 100,000 population) than the rural ones among both the multidimensional poor and the non-poor. The prevalence of tuberculosis (1300 per 100,000 population) was the highest among the elderly multidimensional poor. The prevalence increased with age among both the multidimensionally poor and the non-poor. The prevalence of tuberculosis among the multidimensionally poor males was 620 (per 100,000 population) compared to 350 (per 100,000 population) among the females. Prevalence tuberculosis was relatively more prevalent among smokers than non-smokers.

Table 5 gives the odds ratio of tuberculosis by multidimensional poverty and selected socio-demographic characteristics of respondents. The odds of suffering from tuberculosis was 1.8 times higher [95\% CI: 1.75-1.91] among multidimensional poor compared to the multidimensional non-poor. The likelihood of having tuberculosis increased with age and was higher among the elderly. Smoking was found to be one of the significant predictors of tuberculosis. In comparison to Hindus, Muslims (OR 0.8, 95\% CI: 1.21-1.38) had a lower risk of tuberculosis. Crowded living conditions were also to be a significant predictor of tuberculosis in India.

Figure 3 presents the multidimensional poverty gradient of tuberculosis across states of India with help of adjusted odds ratio (OR). The OR are adjusted for age, sex, place of residence, caste, religion, crowding and smoking habit. Compared to the multidimensional non-poor, the multidimensional poor had significantly higher odds of having tuberculosis across the states of India. For instance, in Andhra Pradesh, the multidimensional poor were $53 \%(\mathrm{OR}=1.53 ; 95 \% \mathrm{CI}: 1.07-2.39)$ more likely to suffer from tuberculosis compared to the multidimensional non-poor. Similarly, the multidimensional poor in Tamil Nadu had a more than $80 \%$ more likely to suffer from tuberculosis than the multidimensional non-poor. In the case of Assam, the chance of having tuberculosis was significantly higher among the multidimensional poor than the multidimensional non-poor. However, the states of Punjab, Kerala, Maharashtra, and Himachal Pradesh did not show significant variations in the prevalence of tuberculosis by multidimensional poverty.

\section{Discussion}

Tuberculosis is a leading infectious disease and remains a major public health challenges in India. With 2.6 million tuberculosis infections and 364 million multidimensional poor, India has the largest number of tuberculosis patients and multidimensional poor worldwide. This is the first-ever study to have estimated the prevalence of tuberculosis among the multidimensional poor and nonpoor across the states of India. We also examined the association of tuberculosis and multidimensional poverty. Our estimates of multidimensional poverty captures multiple domains of deprivation. The following are the salient findings of the study.

First, about one-third of the population in India was multidimensional poor, with large variations across the states of India. Multidimensional poverty was the highest in the state of Bihar (55.6\%) and the lowest in Kerala $(1.0 \%)$. These estimates are consistent with literature $[19,20]$. The prevalence of tuberculosis was the highest in the north-eastern states of Arunachal Pradesh, Manipur, and Nagaland. The state variations observed in the study may be related to human paragonimiasis that 
Table 3 Prevalence of tuberculosis (per 100,000 population/households) among the multidimensional poor and non-poor in the states of India, 2015-2016

\begin{tabular}{|c|c|c|c|c|c|c|}
\hline State & $\begin{array}{l}\text { Number of TB } \\
\text { cases per } 100,000 \\
\text { Multidimensionally } \\
\text { poor persons }\end{array}$ & $\begin{array}{l}\text { Number of TB } \\
\text { cases per } 100,000 \\
\text { Multidimensionally } \\
\text { non-poor persons }\end{array}$ & $\begin{array}{l}\text { Difference } \\
\text { ( } P \text {-value) }\end{array}$ & $\begin{array}{l}\text { Number of TB cases per } \\
100,000 \\
\text { Multidimensionally poor } \\
\text { household (at least one } \\
\text { member in household } \\
\text { suffering from TB) }\end{array}$ & $\begin{array}{l}\text { Number of TB cases per } \\
100,000 \text { Multidimensionally } \\
\text { non-poor household (at } \\
\text { least one member in house- } \\
\text { hold suffering from TB) }\end{array}$ & $\begin{array}{l}\text { Difference } \\
\text { ( } P \text {-value) }\end{array}$ \\
\hline (1) & (2) & (3) & $(4=2-3)$ & (5) & (6) & $(7=5-6)$ \\
\hline $\begin{array}{l}\text { Andhra } \\
\text { Pradesh }\end{array}$ & 460 & 290 & $170(0.014)$ & 1582 & 1108 & $\begin{array}{l}474 \\
(0.0398)\end{array}$ \\
\hline Assam & 490 & 210 & $280(0.000)$ & 2242 & 909 & 1333(0.000) \\
\hline Bihar & 810 & 490 & $320(0.000)$ & 4042 & 2436 & $1606(0.000)$ \\
\hline Chhattisgarh & 260 & 110 & $150(0.000)$ & 1148 & 523 & $625(0.000)$ \\
\hline Gujarat & 280 & 160 & $120(0.002)$ & 1332 & 678 & $\begin{array}{l}654((< \\
0.0001)\end{array}$ \\
\hline Haryana & 440 & 210 & $230(0.000)$ & 2277 & 1012 & $1265(0.000)$ \\
\hline $\begin{array}{l}\text { Himachal } \\
\text { Pradesh }\end{array}$ & 220 & 140 & $80(0.308)$ & 883 & 583 & $300(0.368)$ \\
\hline $\begin{array}{l}\text { Jammu and } \\
\text { Kashmir }\end{array}$ & 230 & 150 & $80(0.001)$ & 1230 & 755 & $\begin{array}{l}475(< \\
0.0001)\end{array}$ \\
\hline Jharkhand & 440 & 240 & $200(0.000)$ & 2060 & 1108 & $952(0.000)$ \\
\hline Karnataka & 300 & 160 & $140(0.000)$ & 1271 & 653 & $618(0.000)$ \\
\hline Kerala & 1590 & 360 & $\begin{array}{l}1230(< \\
0.0001)\end{array}$ & 5162 & 1354 & $\begin{array}{l}3808(< \\
0.0001)\end{array}$ \\
\hline $\begin{array}{l}\text { Madhya } \\
\text { Pradesh }\end{array}$ & 290 & 180 & $110(0.000)$ & 1388 & 829 & $559(0.000)$ \\
\hline Maharashtra & 310 & 230 & $80(0.275)$ & 1346 & 1018 & $328(0.4802)$ \\
\hline Delhi & 1280 & 170 & $\begin{array}{l}1110 \\
(0.000)\end{array}$ & 6022 & 760 & $5262(0.000)$ \\
\hline Odisha & 480 & 260 & $220(0.000)$ & 1937 & 1057 & $880(0.000)$ \\
\hline Punjab & 330 & 150 & $18(0.035)$ & 1542 & 674 & $868(0.0325)$ \\
\hline Rajasthan & 330 & 170 & $160(0.000)$ & 1599 & 816 & $783(0.000)$ \\
\hline Tamil Nadu & 720 & 330 & $390(0.000)$ & 2163 & 1235 & $\begin{array}{l}928(< \\
0.0001)\end{array}$ \\
\hline $\begin{array}{l}\text { Uttar } \\
\text { Pradesh }\end{array}$ & 440 & 280 & $160(0.000)$ & 2276 & 1382 & $894(0.0001)$ \\
\hline Uttarakhand & 360 & 240 & $120(0.007)$ & 1668 & 1010 & $658(0.003)$ \\
\hline West Bengal & 500 & 300 & $200(0.005)$ & 1937 & 1224 & $713(0.003)$ \\
\hline India & 480 & 250 & $230(0.000)$ & 2190 & 1100 & 1090(0.000) \\
\hline
\end{tabular}

TB Tuberculosis

occurs in Arunachal Pradesh, Manipur, and Nagaland, which is in turn associated with tuberculosis [21].

Second, the prevalence of tuberculosis among the multidimensional poor was estimated at 480 (per 100,000 population) compared to 250 (per 100,000 population) among the multidimensional-non-poor in India. The prevalence of tuberculosis was consistently higher among the multidimensional poor than the non-poor in most of the states and across most socio-demographic characteristics. The prevalence of tuberculosis among the multidimensional poor was higher in the economically and the educationally advanced states of Kerala and Delhi, as well as in the poorer states of Bihar. In the case of Kerala and Delhi, greater public awareness on tuberculosis and more availability of and accessibility to health services possibly resulted in a higher detection of the tuberculosis among the multidimensional poor. In the case of Bihar, the widespread prevalence of the disease may have been the probable reason for the high prevalence.

Third, the odds ratio from the logistic regression suggests that the multidimensional poor were significantly more likely to be reported with tuberculosis compared 
Table 4 Prevalence of tuberculosis (per 100,000 population) among the multidimensional poor and non-poor by background characteristics in India, 2015-16

\begin{tabular}{|c|c|c|c|c|}
\hline Background and characteristics & $\begin{array}{l}\text { Prevalence of TB } \\
\text { (per } 100,000 \text { population) } \\
\text { among multidimensional Poor }\end{array}$ & $P$-Value & $\begin{array}{l}\text { Prevalence of TB (per 100,000 } \\
\text { population) among } \\
\text { multidimensional non-Poor }\end{array}$ & $P$-Value \\
\hline \multicolumn{5}{|l|}{ Age } \\
\hline$<15$ & 70 & $<0.0001$ & 50 & $<0.0001$ \\
\hline $15-44$ & 460 & & 180 & \\
\hline $45-59$ & 1150 & & 460 & \\
\hline $60+$ & 1300 & & 750 & \\
\hline \multicolumn{5}{|l|}{ Sex } \\
\hline Male & 620 & $<0.0001$ & 320 & $<0.0001$ \\
\hline Female & 350 & & 180 & \\
\hline \multicolumn{5}{|l|}{ Crowding Condition } \\
\hline Over crowding & 510 & 0.578 & 240 & $<0.0001$ \\
\hline No crowding & 450 & & 270 & \\
\hline \multicolumn{5}{|l|}{ Smoking Behaviour } \\
\hline Not smoking & 460 & $<0.0001$ & 210 & $<0.0001$ \\
\hline Smoking & 490 & & 320 & \\
\hline \multicolumn{5}{|l|}{ Diabetes } \\
\hline Normal & 450 & $<0.0001$ & 180 & 0.118 \\
\hline Diabetic & 760 & & 230 & \\
\hline \multicolumn{5}{|l|}{ Place of Residence } \\
\hline Urban & 520 & $<0.0001$ & 230 & $<0.0001$ \\
\hline Rural & 470 & & 270 & \\
\hline \multicolumn{5}{|l|}{ Caste } \\
\hline SC & 540 & $<0.0001$ & 290 & $<0.0001$ \\
\hline ST & 450 & & 310 & \\
\hline $\mathrm{OBC}$ & 450 & & 250 & \\
\hline Others & 480 & & 230 & \\
\hline \multicolumn{5}{|l|}{ Religion } \\
\hline Hindu & 470 & $<0.0001$ & 250 & $<0.0001$ \\
\hline Muslim & 510 & & 280 & \\
\hline Christian & 660 & & 360 & \\
\hline Others & 480 & & 210 & \\
\hline Total & 480 & & 250 & \\
\hline
\end{tabular}

TB Tuberculosis

to the multidimensional non-poor. Smoking, overcrowding, religion, caste and age were all found to be significant predictors of tuberculosis. Many studies have established smoking as a significant risk factor that increases the risk of tuberculosis in individuals [22, 23]. Smoking increases the risk of progression from infection to disease or the risk of death from tuberculosis [24]. Literature suggests that people who live in overcrowded conditions come into contact with many other individuals, which can be considered a mechanism for the transmission of infectious diseases like tuberculosis [25,
26]. In terms of age, the highest tuberculosis prevalence occurs among the elderly. The multivariate analysis supports that the risk of susceptibility to tuberculosis increases with age.

Our finding as to the higher prevalence of tuberculosis among the multidimensional poor may be related to the fact that people, who are more likely to live and work in poorly ventilated and overcrowded conditions, do not avail quality treatment, which contributes to the spread of the tuberculosisbacteria [27]. Educational achievements are also an important factor in the reduction of 
Table 5 Adjusted odds ratio for predicting tuberculosis by multidimensional poverty and selected risk factors in India, 2015-16

\begin{tabular}{|c|c|c|c|}
\hline Background characteristics & Adjusted OR $(95 \% \mathrm{Cl})$ & Robust Standard Error & $P$-value \\
\hline \multicolumn{4}{|l|}{ Multidimensional Poverty } \\
\hline \multicolumn{4}{|c|}{ Multidimensional Non-Poor (Ref.) } \\
\hline Multidimensional Poor & $1.83^{* * *}(1.74-1.91)$ & 0.04 & $<0.001$ \\
\hline \multicolumn{4}{|l|}{ Age } \\
\hline \multicolumn{4}{|l|}{ Less than 15 (Ref.) } \\
\hline $15-44$ & $4.90 * * *(4.47-5.36)$ & 0.23 & $<0.001$ \\
\hline $45-59$ & $11.58^{* * *(10.55-12.73)}$ & 0.56 & $<0.001$ \\
\hline $60+$ & $16.04^{* * *}(14.59-17.62)$ & 0.77 & $<0.001$ \\
\hline \multicolumn{4}{|l|}{ Sex } \\
\hline \multicolumn{4}{|l|}{ Female (Ref.) } \\
\hline Male & $0.56^{* * *}(0.54-0.59)$ & 0.01 & $<0.001$ \\
\hline \multicolumn{4}{|l|}{ Smoking Behaviour } \\
\hline \multicolumn{4}{|l|}{ No Smoking (Ref.) } \\
\hline Smoking & $1.25^{* * *}(1.2-1.30)$ & 0.03 & $<0.001$ \\
\hline \multicolumn{4}{|l|}{ Crowding } \\
\hline \multicolumn{4}{|l|}{ No crowding (Ref.) } \\
\hline Over crowding & $1.26^{* * *}(1.20-1.32)$ & 0.03 & $<0.001$ \\
\hline \multicolumn{4}{|l|}{ Place of Residence } \\
\hline \multicolumn{4}{|l|}{ Urban (Ref.) } \\
\hline Rural & $1.11^{* * *}(1.05-1.17)$ & 0.03 & $<0.001$ \\
\hline \multicolumn{4}{|l|}{ Religion } \\
\hline \multicolumn{4}{|l|}{ Hindu (Ref.) } \\
\hline Muslim & $1.29^{* * *}(1.21-1.38)$ & 0.04 & $<0.001$ \\
\hline Christian & $1.99 * * *(1.85-2.15)$ & 0.07 & $<0.001$ \\
\hline Others & $1.24^{* * *}(1.13-1.37)$ & 0.06 & $<0.001$ \\
\hline \multicolumn{4}{|l|}{ Caste } \\
\hline \multicolumn{4}{|l|}{ Others (Ref.) } \\
\hline SC & $0.98(0.91-1.05)$ & 0.03 & 0.609 \\
\hline ST & $0.84^{* * *}(0.79-0.89)$ & 0.03 & $<0.001$ \\
\hline $\mathrm{OBC}$ & $0.70^{* * *}(0.65-0.75)$ & 0.03 & $<0.001$ \\
\hline
\end{tabular}

Note: The odds ratio are adjusted for all variables in the table

tuberculosis $[28,29]$. People with no formal education have a poorer knowledge of tuberculosis [30], and its treatment, which is, in turn, associated with an increase in transmission, treatment failure, and death. Awareness of diseases and infections and their spread can be considerably ramped up with increase in educational attainment [31].

The Revised National Tuberculosis Control Program (RNTCP) was launched in 1997 by adopting and formulating the internationally recommended DOTS strategy. In 2006, the WHO launched a new six-point "Stop TB" strategy to achieve the 2015 TB-related Millennium Development Goals. To eliminate tuberculosis in India by 2015 , RNTCP formulated a National Strategic Plan for Tuberculosis 2017-25 with four strategic pillars Detect-Treat-
Prevent-Build (DTPB). Despite the government giving free medicines and giving priority to reducing the disease, the prevalence of tuberculosis has remained high in India. The cases of drug-resistant tuberculosis have also been increasing and are a cause for concern. Tuberculosis can be significantly controlled by make individuals more aware of all aspects of the tuberculosis disease and create a supportive environment for tuberculosis the patients.

The study has a few limitations. First, the study was based on self-reported tuberculosis gathered by NFHS-4. It is possible that in some cases the household respondent may have not revealed the true information. Therefore, the estimated prevalence of tuberculosis is likely to be lower than the actual prevalence in the country. Second, the study may also suffer from the shortcoming of 


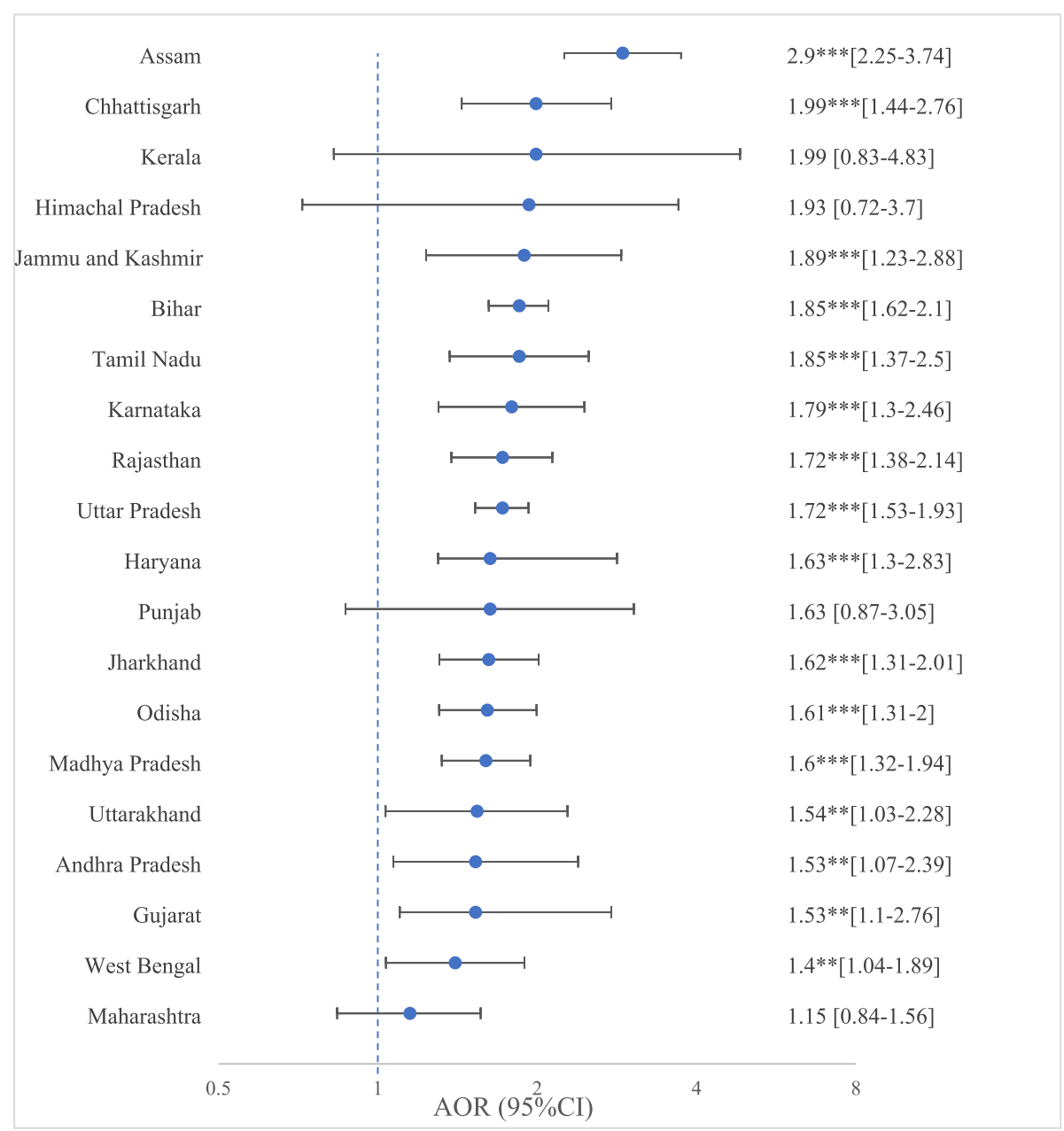

Note: The model was adjusted for age, sex, place of residence, caste, religion, crowding and smoking habit

Fig. 3 Adjusted odds ratio, with 95\% confidence interval of multidimensional poverty gradient of tuberculosis, across the states of India, 2015-16. Note: The model was adjusted for age, sex, place of residence, caste, religion, crowding and smoking habit

biased reporting of tuberculosis by a respondent on behalf of other household members. Third, the analysis of the association between tuberculosis and multidimensional poverty was limited to the variables available in the data set. Information on the state of health infrastructure and the accessibility to and quality of health services was not available in the data set. Despite these limitations, the findings of the study have make a significant contribution to the literature on domain of tuberculosis and multidimensional poverty in India.

The study suggests integrating multiple deprivations in the RNCTP programme so as to effectively implement the "End TB strategy" and reduce the prevalence of the disease among the multidimensional poor. Besides, there is a need to improve social support and increase public awareness to eliminate the stigma attached to tuberculosis,. Comprehensive and long-term interventions are recommended to eliminate tuberculosis in the country.
Acknowledgments

Not applicable.

\section{Authors' contributions}

Conceptualization and design of study: SKM, GV and DP; analysis and interpretation of data: GV and DP; drafting the manuscript: DP, GV and SKM; critical revision of the manuscript for important intellectual content and edit: SKM, GV. Mentoring: SKM. The author(s) read and approved the final manuscript.

\section{Funding}

Not applicable.

\section{Availability of data and materials}

The unit level data is available online in the Demographic Health Survey (DHS) data repository and can be accessed upon request at www.

dhsprogram.com/data/ (DHS, 2018).

\section{Declarations}

Ethics approval and consent to participate

Not applicable. The study is based on secondary data. 


\section{Consent for publication}

Not applicable.

\section{Competing interests}

The authors declare that they do not have any competing interests.

\section{Author details}

1Assam Medical College \& Hospital Dibrugarh, Barbari, Assam, India. ${ }^{2}$ International Institute for Population Sciences, Govandi Station Road, Deonar, Mumbai, Maharashtra 400088, India. ${ }^{3}$ Department of Development

Studies, International Institute for Population Sciences, Mumbai, India.

Received: 28 March 2021 Accepted: 1 November 2021

Published online: 11 November 2021

\section{References}

1. World Health Organization. Global tuberculosis report 2020. World Health Organization; 2020. Available from: https://www.who.int/publications/i/item/ 9789240013131

2. Muniyandi M, Ramachandran R, Gopi PG, Chandrasekaran V, Subramani R, Sadacharam $\mathrm{K}$, et al. The prevalence of tuberculosis in different economic strata: a community survey from South India. Int I Tuberculosis Lung Disease. 2007;11(9):1042-5.

3. Lin CH, Lin CJ, Kuo YW, Wang JY, Hsu CL, Chen JM, et al. Tuberculosis mortality: patient characteristics and causes. BMC Infect Dis. 2014;14(1):5 https://doi.org/10.1186/1471-2334-14-5.

4. Chen L, Bao D, Gu L, Gu Y, Zhou L, Gao Z, et al. Co-infection with hepatitis $B$ virus among tuberculosis patients is associated with poor outcomes during anti-tuberculosis treatment. BMC Infect Dis. 2018;18(1):295. https:// doi.org/10.1186/s12879-018-3192-8.

5. Prada-Medina CA, Fukutani KF, Kumar NP, Gil-Santana L, Babu S, Lichtenstein $F$, et al. Systems immunology of diabetes-tuberculosis comorbidity reveals signatures of disease complications. Sci Rep. 2017;7(1): 1-6. https://doi.org/10.1038/s41598-017-01767-4

6. Hawker Jl, Bakhshi SS, Ali S, Farrington CP. Ecological analysis of ethnic differences in relation between tuberculosis and poverty. BMJ. 1999; 319(7216):1031-4. https://doi.org/10.1136/bmj.319.7216.1031.

7. Barter DM, Agboola SO, Murray MB, Bärnighausen T. Tuberculosis and poverty: the contribution of patient costs in sub-Saharan Africa-a systematic review. BMC Public Health. 2012;12(1):980. https://doi.org/10.1186/1471-24 58-12-980.

8. Oxlade $\mathrm{O}$, Murray M. Tuberculosis and poverty: why are the poor at greater risk in India? PloS one. 2012;7(11):e47533.

9. Darbyshire JH. Tuberculosis: old reasons for a new increase? Br Med J. 1995; 310:0959-8138.

10. Janssens JP, Rieder HL. An ecological analysis of incidence of tuberculosis and per capita gross domestic product. Eur Respir J. 2008;32(5):1415-6. https://doi.org/10.1183/09031936.00078708.

11. Alkire S, Santos ME. Acute multidimensional poverty: A new index for developing countries. United Nations development programme human development report office background paper; 2010.

12. Alkire S, Kanagaratnam U, Suppa N. The global multidimensional poverty index (MPI); 2019

13. UN SDGs. (2015). Transforming our world: The 2030 Agenda for Sustainable Development. A/RES/70/1. Available from: https://sustainabledevelopment. un.org/post2015/transformingourworld.

14. Mazumdar S, Satyanarayana S, Pai M. Self-reported tuberculosis in India: evidence from NFHS-4. BMJ Glob Health. 2019;4(3):e001371. https://doi. org/10.1136/bmigh-2018-001371.

15. ICF I. India National Family Health Survey NFHS-4 2015-16. Mumbai: IIPS and ICF; 2017.

16. Poverty O, Human Development Initiative. Global Multidimensional Poverty Index 2018: The most detailed picture to date of the world's poorest people. UK: University of Oxford; 2018. Available from: https://ophi.org.uk/ global-multidimensional-poverty-index-2018-the-most-detailed-picture-to-da te-of-the-worlds-poorest-people/.

17. Alkire, S., Oldiges, C., \& Kanagaratnam, U. (2018). Multidimensional poverty reduction in India 2005/6-2015/16: still a long way to go but the poorest are catching up. Oxford Poverty and Human Development Initiative (OPHI).

18. Alkire S, Kanagaratnam U. Multidimensional Poverty Index Winter 2017-18: Brief methodological note and results, OPHI Methodological Notes, vol. 45; 2018.
19. Vasishtha G, Mohanty SK. Spatial pattern of multidimensional and consumption Poverty in districts of India. Spatial Demography. 2021:9(2):128. https://doi.org/10.1007/s40980-021-00089-4.

20. Cowling K, Dandona R, Dandona L. Social determinants of health in India: progress and inequities across states. Int J Equity Health. 2014;13(1):1-2. https://doi.org/10.1186/s12939-014-0088-0.

21. Rekha Devi K, Narain K, Mahanta J, Deori R, Lego K, Goswami D, et al. Active detection of tuberculosis and paragonimiasis in the remote areas in northeastern India using cough as a simple indicator. Pathogens Global Health. 2013;107(3):153-6. https://doi.org/10.1179/2047773213Y.0000000086.

22. Saha A, Sharma YK, Kulkarni PK, Saiyed HN. Risk of tuberculosis and fuel use: a population study. Occup Environ Med. 2011;68(12):934.

23. Pokhrel AK, Bates MN, Verma SC, Joshi HS, Sreeramareddy CT, Smith KR. Tuberculosis and indoor biomass and kerosene use in Nepal: a case-control study. Environ Health Perspect. 2010;118(4):558-64. https://doi.org/10.1289/ ehp.0901032.

24. Den Boon S, Van Lill SW, Borgdorff MW, Verver S, Bateman ED, Lombard CJ, et al. Association between smoking and tuberculosis infection: a population survey in a high tuberculosis incidence area. Thorax. 2005;60(7):555-7. https://doi.org/10.1136/thx.2004.030924.

25. Cantwell MF, McKenna MT, McCRAY EU, Onorato IM. Tuberculosis and race/ ethnicity in the United States: impact of socioeconomic status. Am J Respir Crit Care Med. 1998;157(4):1016-20. https://doi.org/10.1164/ajrccm.157.4. 9704036.

26. Lienhardt C. From exposure to disease: the role of environmental factors in susceptibility to and development of tuberculosis. Epidemiol Rev. 2001; 23(2):288-301. https://doi.org/10.1093/oxfordjournals.epirev.a000807.

27. Pond MA. Interrelationship of poverty and disease. Public Health Rep. 1961; 76(11):967. https://doi.org/10.2307/4591336.

28. Desalu OO, Adeoti AO, Fadeyi A, Salami AK, Fawibe AE, Oyedepo OO. Awareness of the warning signs, risk factors, and treatment for tuberculosis among urban Nigerians. Tuberculosis Res Treatment. 2013;2013:1-5. https:// doi.org/10.1155/2013/369717.

29. Yadav SP, Mathur ML, Dixit AK. Knowledge and attitude towards tuberculosis among sandstone quarry workers in desert parts of Rajasthan Indian J Tuberculosis. 2006;53(4):187.

30. Sreeramareddy CT, Kumar HH, Arokiasamy JT. Prevalence of self-reported tuberculosis, knowledge about tuberculosis transmission and its determinants among adults in India: results from a nation-wide crosssectional household survey. BMC Infect Dis. 2013;13(1). https://doi.org/10.11 86/1471-2334-13-16.

31. Khan JA, Irfan M, Zaki A, Beg M, Hussain SF, Rizvi N. Knowledge, attitude and misconceptions regarding tuberculosis in Pakistani patients. J Pakistan Med Assoc 2006:56(5):211.

\section{Publisher's Note}

Springer Nature remains neutral with regard to jurisdictional claims in published maps and institutional affiliations.

Ready to submit your research? Choose BMC and benefit from:

- fast, convenient online submission

- thorough peer review by experienced researchers in your field

- rapid publication on acceptance

- support for research data, including large and complex data types

- gold Open Access which fosters wider collaboration and increased citations

- maximum visibility for your research: over $100 \mathrm{M}$ website views per year

At $\mathrm{BMC}$, research is always in progress.

Learn more biomedcentral.com/submissions 